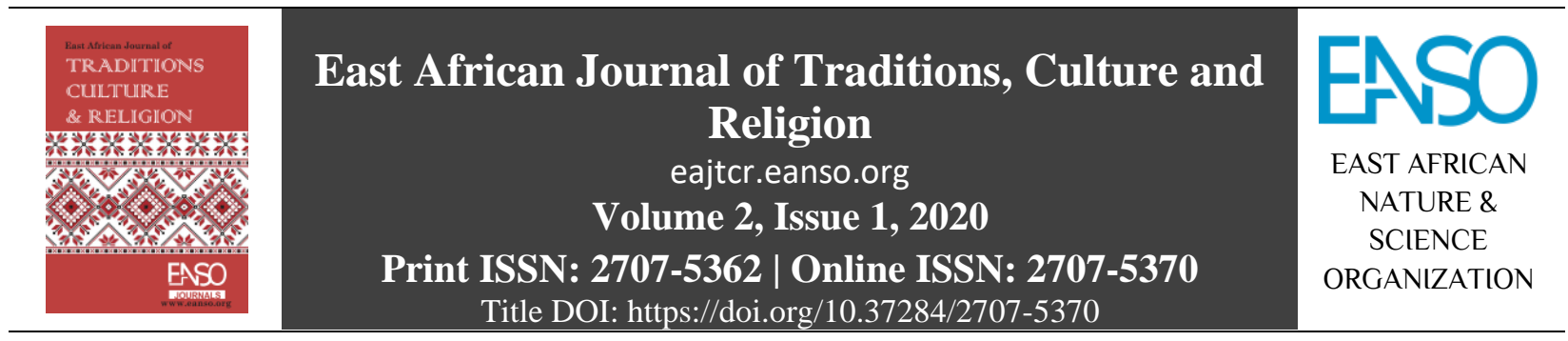

Original Article

\title{
African Art Music and the Drama of Christian Worship among Baptists in Nigeria
}

\author{
Rev. Isaac Osakpamwan Ibude, $P h D^{1^{*}}$ \\ ${ }^{1}$ Department of Music, Faculty of Humanities, University of Port Harcourt, Port Harcourt, Rivers State, Nigeria. \\ *Author for Correspondence Email: isaac.ibude@uniport.edu.ng. \\ * ORCID: https://orcid.org/0000-0002-9927-4997.
}

Article DOI: https://doi.org/10.37284/eajtcr.2.1.226

Date Published:

22 October 2020

\section{ABSTRACT}

Church music is purpose-driven and functional art. The search for authentic

Keywords: African experience in Christian worship among Nigerian Baptists brought about the introduction of art music compositions into the drama of worship. The paper

Church Music, discusses the development and contextualisation of Baptist worship by the

Art Music, inclusion of new music(s) written, composed and performed by Africans for the

Drama,

Worship,

Contextualisation. purpose of the liturgy, serving as a voice within the culture. The research adopted an ethnographic research design. Data were collected from published works and recorded art music compositions, content analysis of worship bulletins, personal interviews with art music composers, choirmasters and pastors within the denomination. Textual analysis of art music compositions reveals that there are four different modes of communication in the drama of worship: Kerigmatic, Leitourgic, Koinonia, and Reflexive. The emergence and performance of art music compositions in the drama of worship have facilitated communication, indigenisation and acculturation of Christian worship among Baptists in Nigeria.

\section{APA CITATION}

Ibude, I. (2020). African Art Music and the Drama of Christian Worship among Baptists in Nigeria. East African Journal of Traditions, Culture and Religion, 2(1), 72-82. https://doi.org/10.37284/eajtcr.2.1.226

\section{CHICAGO CITATION}

Ibude, Isaac. 2020. "African Art Music and the Drama of Christian Worship among Baptists in Nigeria". East African Journal of Traditions, Culture and Religion 2 (1), 72-82. https://doi.org/10.37284/eajtcr.2.1.226.

\section{HARVARD CITATION}

Ibude, I. (2020) “African Art Music and the Drama of Christian Worship among Baptists in Nigeria”, East African Journal of Traditions, Culture and Religion, 2(1), pp. 72-82. doi: 10.37284/eajtcr.2.1.226. 
IEEE CITATION

I. Ibude, "African Art Music and the Drama of Christian Worship among Baptists in Nigeria”, EAJTCR, vol. 2, no. 1, pp. 72-82 Oct. 2020.

\section{MLA CITATION}

Ibude, Isaac. "African Art Music and the Drama of Christian Worship among Baptists in Nigeria." East African Journal of Traditions, Culture and Religion, Vol. 2, no. 1, Oct. 2020, pp. 72-82, doi:10.37284/eajtcr.2.1.226.

\section{INTRODUCTION}

The church, from its inception, has been at the forefront of promoting the use of music in worship, proclamation, education and pastoral care. The development of church music among evangelicals can be traced to the $16^{\text {th }}$-century protestant reformation. The reformation brought about change in worship patterns informed by theological and hermeneutical considerations with respect to the bible, especially the New Testament. This 'new understanding' found expression through the use of hymns, canticles and responses in the liturgy of the church. As Vidal (1986) observed, the form of music used by the Methodist and Anglicans in worship services was imported into Southern Nigeria between 1841 and 1902 by European missionaries during the Colonial era.

The situation was not different when the Baptist mission began her missionary efforts in the mid1850 in Abeokuta. For so many years, mission churches were led by foreign missionaries and their worship experiences were European both in orientation and actual performance. The need to contextualise Christian worship among mission churches in Nigeria to reflect indigenous culture was birth in the late $19^{\text {th }}$ and $20^{\text {th }}$ centuries during the growth of nationalism. Omibiyi-Obidike (1979) further stressed that it was during this period that Nigerian creative music was developed in response to the need to reshape Christianity to suit African customs.

Church music and its practice by Christians during worship services are not immune to external pressures. Response to such pressures Kudila (2005) observed can be seen in the people's ability to navigate change in such a way that new elements evolve naturally to enhance and accommodate cultural stylistics. This phenomenon opened the door for contextualisation of church music as an indigenous expression in worship. Sadoh (2009) posits that Nigeria art music could be termed 'intercultural music' which he explained is the conjoining of indigenous creative principles by composers with foreign elements. The composers and performers are primarily Christians since this genre of music originated from the church. Art music, therefore, is defined as a product of syncretic efforts brought about by the synthesis of indigenous and western creative elements by composers leading to the contextualisation of Christian worship. This paper seeks to discuss the development and contextualisation of Christian worship among baptists in Nigeria through art music compositions.

\section{A Brief History of Pioneering Baptist Missionary Efforts in Nigeria}

Missionary efforts of the Southern Baptist Convention (SBC) began in South West Nigeria over one hundred and seventy-three years ago. The decision to come to African was adopted during the Triennial Convention which began on the $8^{\text {th }}$ of May, 1845 , in response to socio-economic challenges arising from the slave trade (Collins, 1993). During that session, the Foreign Mission Board was inaugurated to oversee mission work in China, Brazil and Africa. In 1849 the Foreign Mission Board sent Rev. Thomas Jefferson Bowen as the pioneering missionary to Africa. Bowen was born on the $2^{\text {nd }}$ of January, 1814 in Jackson County, Georgia and was married to Miss Laurenna Henrietta Davis in May, 1853 in the USA (Okedara and Ajayi, 2004: 5).

Bowen arrived Badagry on the $5^{\text {th }}$ of August, 1850. $\mathrm{He}$ joined and became a guest of Methodist Missionaries in Abeokuta for eighteen months during when he learned the Yoruba language leading to the publication of a book titled Grammar and Dictionary of Yoruba Language in 1858. Bowen moved from Abeokuta to Ijaye where he had his first convert by name Tella whom he baptised on the 23rd of July, 1854. There at Ijaye, 
he built the first Chapel and mission house (Ajayi, 2010). From Ijaye the work spread to Lagos, Ogbomoso and other towns in the Southwest. Over seventeen decades; the mission effort of Bowen grew and on 10-14th of March 1914 at First Baptist Church Idikan, Ibadan the 'Yoruba Baptist Association' was inaugurated with Mojola Agbebi as the first President. Following the success and growth of the mission work in the Southern and Northern part of the country, in the same manner, the congregation in 1918 in Calabar decided to change her name from 'Yoruba Baptist Association' to the 'Nigerian Baptist Convention' (NBC) in 1919, to give it a national outlook (Ayokunle, 2014). The work has spread beyond Nigeria to other countries in Africa: The Republic of Benin, Cote D' Ivoire, Mali, Sierra Leone, Mozambique, Chad, Niger and Burkina Faso, United Kingdom and the United States of America are experiencing the impact of the growth of the Nigerian Baptist Convention (Interview F. Adewumi, the 2nd of November, 2018).

\section{Earliest Order of Baptist Worship}

Christianity as a religion spread across major areas in the ancient world and then Greco-Roman provinces which include Rome and later the continent of African through Missionary activities. In the mid and late $19^{\text {th }}$ century, the missionaries approached their work from three different directions which include the establishment of churches, schools and hospitals. Music was used by missionaries and later by indigenous preachers as a major tool to spread the good news and engage in worship practices. Ibude (2004, p. 37) observed that their approach to worship practices were expressions of their theological bias and culture.

The earliest form of worship order which held twice on Sunday each week by Baptists was developed in 1609 by John Smith. It was entirely scriptural and had five different elements as follows: Prayer, Scripture, Exhortation (More than one preacher), Prayer (By the minister), Offering (For the poor) and Benediction. However, in the late nineteenth century, the earlier scripturally-based order was altered and replaced with a new one developed by John A. Broadus in 1870. Its expanded structure comprised of Choral call to worship (choir) Invocation, Hymn of worship (Read before singing), Devotional scripture reading, Hymn of devotion, Principal prayer, Hymn of Preparation, Sermon, Prayer, Final hymn, Offering, Lord's Supper and finally Benediction (Hallbrooks, 1994).

Baptist worship in Nigeria promoted the use of indigenous language from its inception as a tool for evangelism. However, other aspects of the indigenous culture such as music, dance, and indigenous art forms were forbidden and not slated in the order of worship by the missionaries. Worship practices in the 1920s were solemn as the only instrument allowed for accompanying the hymns was the Organ. The drums, dancing and hand-clapping were prohibited in worship (Ibude, 2004).

However, over the past thirty years, corporate Christian worship among various congregations that make up the Nigerian Baptist Convention has encouraged contextualisation of worship to reflect the indigenous culture of the people wherever such congregations are located within Nigeria and beyond. According to S. O. Auda (Interview the 15th of December, 2018), there is no particular 'approved' order of worship in the NBC as each congregation is autonomous and congregational in her practice of Church government. Each congregation is at liberty to plan their order of worship under the leadership of a trained pastor or church leader. This has helped to facilitate the indigenisation and contextualisation of cooperating Christian worship across the NBC.

A review of aspects/elements of worship in bulletins at annual sessions of the Nigeria Baptist Convention in the past ten years shows certain patterns in the use and incorporation of contemporary art music in the worship services. Content analysis of the order of worship shows that there are acts associated with entrance and dismissal. Basically, the drama of worship is divided into four phases with one flowing into the other without scenes in a typical drama as follows: Entrance into God's presence, the hearing of the preached word, response with thanksgiving and dismissed/empowered to go and serve.

The performance of art music compositions in worship services by the choir in most cases comes before the preached word. Furthermore, the rendition of art music compositions comes as 
response/acts of thanksgiving to God in the drama of worship. The performers of these compositions are initially the choir and as the composition becomes familiar you here spontaneous participation by the congregation as the choir sings. At this level of participation, the rendition becomes the song of the congregation not a 'special' rendition by a select group.

\section{CONCEPT OF CORPORATE CHRISTIAN WORSHIP AS DRAMA}

The term 'worship' is coined from an Anglo-Saxon 'Weorthscipe' which means attributing worth to someone or something, which later developed to 'worth-ship' and finally 'worship'. In the light of biblical understanding and historical development, worship as a term has come to mean an act of service offered to God for His worth. Webber (1996, p. 18), noted that worship 'is the most important action the church is to be about'. This action is between God and His people which Davidson (2002, p. 2) defines as:

'... a dramatic, dynamic, dialogical encounter between the triune God of the Bible and His people in which God speaks and/or acts to reveal Himself and His will and God's people respond to Him in appropriate biblical ways'

Furthermore,

"Christian worship is a festival of corporate reenactment of rites... for the spiritual experience of God's presence, leading to transformation and renewal of one's commitment as a conscious divine agent in the world" (Ibude, 2004, p. 7).

The above definitions agree with Kierkegaard's comparison that parallels worship to a drama that has a storyline and effectively progresses to the denouement. The congregational actors, the ministers and the choir serve as prompters to work together to communicate the 'play', not themselves. In other words, members of the congregation are the 'actors,' ministers and choir as 'prompters' and God are present as the 'audience' (Kierkegaard, 1961, p. 181). The emphasis here is that there is an on-going dialogue with God in the form of revelation (who God is and what God says to us) and response (what we become by His grace and say to God in praise, confession, thanksgiving, petition and dedication) which the 'script' through the Holy Spirit must accommodate to make worship meaningful. Art music compositions find expression in communicating the storyline/plot at the beginning, middle and end of the worship services.

\section{Developments and Contextualisation of Art Music in Baptist Worship}

The need to situate Christian worship in the indigenous culture continues to the present day. Christopher Birkett in 1871 was the first, as recorded Jones (1976, p. 17) in the preface of a Hymnbook, Ingoma, or Penult Psalm Tunes, to raise the banner of dissatisfaction as a serving missionary at Fort Beaufort in the South-East of Cape Province in South Africa. Similarly, Shaffer (1956); Idowu (1965); and Cray (1987) observed how missionaries were biased viewing our culture as pagan, therefore inappropriate for worshipping the Creator. Over time, the missionaries became more fluent in the language of the people, Western hymns translated into the native dialects were introduced in abundance and strict care was taken that the melody and rhythm of the original hymn were retained which resulted in horrendous communication of meanings not intended from the European hymn text from which they were translated to indigenous language due to its tonality when set to western tunes.

The quest to make worship relevant, as well as foster congregational singing among Baptists in Nigeria, led to the publication of the first Yoruba Baptist Hymn Book in 1907. A minimum of four songs was sung in each worship service in line with the order of worship developed in 1870. Ajayi (2010, p. 356) noted that this imported order of worship accommodated only European hymns translated into the Yoruba language set to Western tunes. During this period there were schisms within various denominations when converts among other issues began to call for the indigenisation of mission churches in every area of church life. The first and great historical schism in church history in Nigeria took place in 1888 at the First Baptist Church, Lagos brought about by growing racial awareness and desire for self-determination (Ajayi, 2010, p. 70). Self-determination as to allow 
converts to lead and express themselves through indigenous music and culture of the people (Omojola, 2005) in the worship life of the church.

The schism in 1888 brought about a new era of worship renewal through the use of indigenous music and other art forms rooted in our culture and traditions. In the same vein, $1914 \mathrm{AD}$ to the present time as observed by Tunji Vidal (1977) is the era of the "New music" among the Christian community. The Baptist denomination as at this time in 1914 was twenty-six years into worship renewal and contextualisation through indigenous art forms. The new music developed along with certain patterns as follows: Europeanization of Yorùbá texts by the use of European hymn tune and chants, the adaptation of existing Yorùbá indigenous melodies to newly composed Christian lyrics and a form which involves original musical composition with new melodies and new texts using (a) the verse form, (b) the call and response form and (c) the through-composed form (Vidal, 1977).

Prominent among those in the forefront of contextualising worship through indigenous music in the Baptist denomination was Rev. Dr. Mojola Agbebi of the Native Baptist Church who before his ordination as a Baptist minister was known as David Brown Vincent (Atanda, 1988). He insisted on the use of Yoruba indigenous melodies and compositions with new text in Christian worship among Baptists. Furthermore, in the quest to contextualise Christian worship Omojola (1995) noted that Rev. Dr. Mojola Agbebi instructed Baptist churches in Ekiti land not to use European hymns for seven years during worship services.

Baptist work in Nigeria before the 1890s was restricted to Southwest Nigeria. The evangelistic effort to other parts of Nigeria by indigenous preacher gained ground from 1893. The work spread to Buguma and Niger Delta areas in the then Eastern and Mid-West Nigeria through the effort of a European Baptist Missionary, Rev. William Hughes (Ajayi, 2010, p. 83). Rev. Dr. Mojola Agbebi in 1898 took over the leadership of the church and encouraged the church members to read, write and compose songs in Kalabari which were used in worship services he conducted (George, 2010, p. 20). This initiative, according to Suku B. Ngiangia (Interview the 10th of December, 2018) gave rise to a musical heritage among converts, a major tool used for communicating the gospel among Kalabari up to this contemporary time.

\section{Art Music Practitioners in the NBC}

The advent of Christian missionary enterprise and European civilisation as noted by Omojola (1994, p. 533) led to the emergence of a new musical idiom known as Nigerian art music. Adegbite (2001: 77) further explained that this new musical idiom in both vocal and instrumental medium employed certain musical approaches of western origin in writing African music leading to cross-fertilisation and synthesis called African art music.

Art music composers within NBC can be categorised into two groups as follows: first, those who received their training by participating in church choirs, music workshops and the then Baptist College Iwo now Bowen University where teachers were trained for Baptist mission schools. Examples are $\mathrm{Mr}$ Emmanuel Akinyemi Magbagbeola (1923-1979), Moses Ojo (1932-), Titilope Ayorinde (1960- ), Sampson Beals, Chukwuemeka Etus, Paul Thomson and many others. These categories were not formally trained as musicians in any higher institution but are gifted in the art of composition having developed themselves through Music workshops organised by the NBC for over four decades at national and regional levels within the denomination. $\mathrm{T}$. Takpatore (personal communication. the 12th of December, 2018) noted that in the past fifteen years, the NBC had organised more music workshops at state and regional levels to train and enlist more church musicians, some of whom are composers of the different musical genre into the worship life of the churches within the denomination.

The second category is exemplified by the following: Debo Akinwumi (1956-2006), Emurobome Idolor, Ekerete Iyang, Taye Adeola, Emmanuel Fashipe, Kenny Adetoye, Ishaya J. Yarison, Dele Ogunlade, Eleazer Ihejirika and so on. These and many others studied music as professionals in Colleges of Education, Polytechnics, Universities, Baptist Bible Colleges and Seminaries in Nigeria and or overseas. Many of whom have used folk melodies in their 
compositions making the drama of Christian worship meaningful and contextual by weaving appropriate biblical text into their compositions. This feat was made possible by this group of composers in incorporating features of indigenous African music to create choral works suitable for worship.

\section{Impact of Art Music Compositions in the Drama of Worship}

Church music is meant to serve the liturgy in the area of congregational worship, proclamation, education and pastoral care. Church music can perform this role efficiently when communicated in musical idioms understood by the people within a cultural context. Art music as a form is functional and well able to convey and communicate the intended liturgical text for worship either as revelation or response. The church according to Pass (1989) communicate via three different kinds of moods, that is, Kerygmatic (from speaker to the congregation), Koinonia (between members of the congregation) and leitourgia (from congregation to God) by which the church fulfils her mission any time the congregation gathers for worship. These modes of communication are evident in the drama of worship as exemplified in the texts set to music by art music composers in the NBC.

Liturgical text in the Kerymatic mode is usually drawn directly or are a paraphrase of biblical text or stories. The address situation here is that of a preacher proclaiming the message of Christ. It is a mode of communication where one person, that is, a monologue or group of persons addresses many. This one-way communication makes the choir during presentation speak to the people as if God were speaking to them. A typical example of is Deboh Akinwumi's anthem composed in Yoruba titled "Oti Jinde" (He is Risen) (Akinwumi, 2008), centred on the suffering, death and resurrection of Christ as presented in the Gospels in the New Testament. Another example in this category is "Kauna" (Yarison, 2003) in Hausa by Ishaya Yarison based on John 3:16 which talks about the love of God for the world.

Art music compositions in Kerigmatic mode are usually performed in the drama of worship before the preacher comes to present the message at a particular point in the order of worship, which most often is related to the subject or theme of the message. Such compositions help to prepare and deepen the understanding of the congregation as they listen to the presentation of the preacher. Art music compositions cited above put the message of God in the language of the people and at the same time in a musical form that evolved from within the culture. In the drama of worship, two things happen as earlier reiterated. That is, God speaks to His people through His Word and the congregation responds through prayer and commitment to Him.

Art music compositions apart from conveying the voice of God to the people, also convey the congregations' response to God. This mode of communication is called a leitourgia mode. Congregational responses are captured in the form of praise, prayer and commitment to the service of God and humanity. One of such anthems by Emurobome Idolo is "Glory, Hallelujah to His name" (Idolo, 2008). The composition is a song of praise in appreciation of the goodness, mercy, blessings and all His kindness. Idolo, in this composition, used a four-part harmonic system from a pentatonic scale used in the performance practice of indigenous music in Okpe culture. Another example of art music composition in this category is "We Proclaim Your Majesty" (Thompson, 2017, p. 48-49). The song is directed vertically upward in praise of God as the faithful, awesome and precious father.

Apart from God speaking to his people (kerygmatic mode) and the people responding (leitourgia mode) to God in praise, prayer and submission to His will as exemplified in the compositions cited earlier, the third mode of communication in the drama of worship is Koinoniac mode. This address situation allows for speaking to one another. The dialogue is horizontal and affirms the group. Members of the congregation listen to the words of comfort and encouragement from the performer. This address situation is represented in the song "Be Patient to the End" (Inyang, 2014). The songs encourage one another to be patient to the end during trials, sickness, and when their soul is cast down. Koinonia is all about fellowship devoid of hierarchical concerns; the focus is on equality and reciprocity in times of sorrow and difficulty as 
exemplified in the Yoruba song "Nitori Re Ati Emi" (Because of You and Me) (Akinwumi, 2008).

The fourth kind of address found in texts of contemporary art music compositions used in Baptist worship is the reflexive mode. These are responses from the individual to commit his or her life to God. It is personal and conveys the needed response to God's revelation through the spoken word. Such songs carry the pronoun 'I' as seen in the songs "I Will Enter His Presence" and "I will sing to the Lord" (Inyang, 2008). This mode of communication is an inner conviction and commitment of following God's injunction by promising to become the best and be obedient to God's injunction in a composition titled "I Will Do My Best" (Rohm, 1992) composed by Sola Fasipe as a song of commitment and promise to do the best for Jesus.

Art music compositions by the composer in the Nigeria Baptist Convention have addressed two major aspects of worship which have to do with revelation as in God communicating to His people and responses through praise, adoration, prayer, thanksgiving and so on. This form of music has not only added to the number of musical styles accessible for use in the drama of worship to worship leaders and planners but has enriched the congregation spiritually by making worship service truly Nigerian.

\section{CONCLUSION}

The growth and spread of Baptist missionary enterprise beyond the South-West of Nigeria began with the historic schism at First Baptist church Lagos in 1888. Reform through the contextualisation of worship is a major factor among others responsible for the spread of Baptist churches cooperating together under the umbrella called the Nigerian Baptist Convention. The quest for cultural nationalism through music and other art forms led to the emergence of indigenous pastors, church leaders and composers who not only dropped the order of worship that was western in nature but created a new template that allows for the incorporation of art music compositions at a different time in the drama of worship. Content analysis of worship bulletins and texts of art music compositions reflected four different modes of communication in the drama of worship. The directions of communication range from vertical, horizontal and reflexive as exemplified in the texts of art music compositions performed in worship. The inclusion and performance of art music compositions by clergy, choir and members of the congregation have further enhanced and promoted the contextualisation and indigenisation of the drama of worship within the Nigerian Baptist Convention churches.

\section{REFERENCES}

Adegbite, A. (2001). The present state of development of African art music in Nigeria. In Omíbíyì-Obidike, M. A., African art music in Nigeria: Felá Sówándé memorial (pp. 77-82). Lagos: Stirling-Horden Publisher (Nig.) Ltd.

Ajayi, S. A. (2010). Baptist Work in Nigeria, 18502005: A Comprehensive History. Ibadan: BookWright Publishers.

Akinwumi, D. (2008). Yoruba Anthems (Vol. 1).

Atanda, J. A. (1988). Baptist churches in Nigeria 1850-1950. Ibadan: University Press Limited.

Ayokunle, S. O. A. (2014). A century of Nigerian Baptist Convention life: a call for celebration and renewal. In A century of Nigerian Baptist Convention: a call for celebration and renewal (pp. 27-45). Ogbsomoso: Nigerian Baptist Theological Seminary.

Collins, T. (1993). The Baptist Mission of Nigeria: 1850-1993; a history of the Southern Baptist Convention Missionary Work in Nigeria. Ibadan: Associated Book- Makers Nigeria Limited.

Cray, G. (1987). In spirit and in truth. London: Hodder \& Stoughton.

Davidson, P. O. (2002). Come Let Us Worship! Biblical Foundations for Cooperate Christian Worship. Ibadan: Publishing Board, Nigerian Baptist Convention.

George, C. T. T. (2010). A brief history of Baptist work in the Niger Delta 1893-1950. Port Harcourt: TMG Communications. 
Hallbrooks, G. T. (1994). A Baptist model of worship' In Webberm R. E. (Eds), The complete library of Christian worship: twenty centuries of Christian worship (pp. 231-235). Nashville, Tennessee: Star Song Publishing Group.

Ibude, I. O. (2004). Indigenous Music in Worship: A Case Study of First Baptist Church Okelerin, Ogbomoso. M.A Thesis. University of Ibadan.

Idolo, E. (2008). African choral series vol. 1. Lagos: Stirling-Horden Publishers Ltd.

Idowu, B. (1965). Towards an indigenous church. London: Oxford University Press.

Inyang, E. O. (2014). Salvation songs for choir and congregation. Lagos: Revelation Printers.

Jones, A. M. (1976). African hymnody in Christian worship. Gmelo: Mambo Press.

Kierkegaard, S. (1956). Purity of heart is to will one thing. Steere, D. V. (Trans.). New York: Harper \& Row.

Kudila, J. (2005). Christian music as indigenous African: appropriation and accommodation. In Omojola, B., \& Dor, G. (Eds.), Multiple interpretations of dynamics of creativity and knowledge in African music traditions: A festschrift in honor of Akin Euba on the occasion of his $70^{\text {th }}$ birthday (pp. 211-225). Point Richmond: Music Research Institute Press.

Okedara, J. T., \& Ajayi, S. A. (2004). Thomas Jefferson Bowen: Pioneer Baptist Missionary to Nigeria, 1850-1856. Ibadan: John Archers.

Omibìyí, M. 'Nigerian musicians and composers' Nigerian magazine No. 128-129, （1979):7880.
Omíbíyì-Obidike, M. A. (2001). African art music in Nigeria: Felá Sówándé memorial. Ibadan, NG: Stirling-Horden Publishers (Nig.) Ltd.

Omojola, B. (1995). Nigerian art music. Ibadan: Institut Francais de Recherche en Afriqu.

Omojola, O. F., \& Bankole, A. (1994). Contemporary art music in Nigeria: an introductory note on the works of Ayo Bankole. Africa, 533-543.

Pass, D. B. 91989). Music and the church. Nashville, Tennessee: Broadman Press.

Rohm, A. H. (1992). Music for the church. Ibadan: Nigerian Baptist Store Ltd.

Sadoh, G. (2009). Modern Nigerian music: the postcolonial experience. The musical times, 150(1908), 79-84.

Shaffer, J. (1956). Experiments in indigenous church music among the Batetela. African Music: Journal of the International Library of African Music, 1(3), 39-42.

Thompson, P. (2017). Hymns and worship. Port Harcourt: Beulah Publishing House.

Vidal, T. (1977). Traditions and history in Yoruba music. Nigerian Music Review, 1, 76-96.

Vidal, T. (1986). The Westernization of African Music: A Study of Yorùbá Liturgical Church Music. Annals of the Institute of Cultural Studies University of Ife, 70-82.

Webber, R. E. (1996). Blended Worship: Achieving Substance and Relevance in Worship. Massachusetts: Hendrickson Publisher, Inc.

Yarison, I. J. (2003). Celebration: A collection of original anthems in English and Hausa. Ogbomoso: Amstrong Plus Communications. 


\section{APPENDIX}

\section{We Proclaim Your Majesty (Paul Thompson)}

1. Faithful Father, doer of all things, all creation bows to you. Men and angels fall before You in reverence of Your Throne! Be exalted in Your place, You alone deserve all praises!

Faithful father, doer of all things, We proclaim Your Majesty.

2. Awesome Father, Our Defender, You are true in all your ways!

Lo, Your name is higher than all names, in this tower we are safe. You have shielded us in time, in Your arms we have remained Awesome Father, Our Defender, We proclaim your Majesty

3. Precious Jesus, gentle saviour, You have loved us, here we are! Moving still by your great power, You have blazed the trail for us! You're the same whose ones we are; You have made us as You are, Precious Jesus, gentle Saviour, We proclaim Your Majesty.

\section{I Will Enter His Presence (Ekerete O. Inyang)}

I will enter into the house of the Lord my King

I will enter into the presence of the Lord and praise Him.

I will enter His worship. I will enter, I will enter, Amen.

\section{I Will Sing to My Lord (Ekerete O. Inyang)}

All my life I will sing to the Lord, all my life I will sing I will sing and rejoice, may His glory endure forever All my life 1 will sing to my Lord, all my life I will sing. (Fine)

1. Jesus my Lord of all creation I lift my voice unto You my King Clothed in splendour and majesty, Creator, Lord and Sustainer.

2. Come all ye Nations all around me. Join me in praising Jehovah King Who makes the cloud His Chariots to ride; Creator, Lord and Sustainer

3. I have a Saviour, I have a King; His name's Jesus the Great I AM.

He wraps Himself with light as a garment, and stretch the heavens like a tent

4. Come all creation, come souls of men, let's sing our praises to our Creator Who set the earth on its foundation, Creator, Lord and Sustainer

5. Sing hallelujah, sing Hallelujah, sing hallelujah to Christ the King;

Sing hallelujah to Emmanuel; Creator, Lord and Sustainer. (D. C. al fine) 
East African Journal of Traditions, Culture and Religion, Volume 2, Issue 1, 2020

Article DOI: https://doi.org/10.37284/eajtcr.2.1.226

\section{I Will Do My Best (Sola Fasipe)}

1. I will do my best for Jesus. Sing unto the Lord my Soul (2 Times) I will praise I'm with my whole heart, I will worship Christ my King I will do my best for Jesus. Sing unto my Lord my Soul

2. I will take my cares to Jesus. Run unto the Lord my feet (2 Times) Will trust His grace and goodness. To supply my every need. Will take my cares to Jesus. Run unto the Lord my feet.

\section{Glory, Halleluja to Hia Name (Emurobome Idolo)}

Praise to God for all His goodness; Hallelujah to His name (2Times)

For His goodness, For all His mercies and all His blessings all through our days Hallelujah to His name. Ti Ka ti ka ka ti ti ka. Glory to God for His goodness, for all His tender mercies and His loving kindness. Hallelujah ever to His name Glory to God for all His goodness, for all His tender mercies Hallelujah. Glory, glory Hallelujah forevermore to His name.

\section{Kauna - Love (Ishaya J. Yarison)}

Alla yayi kaunar duniya ya bada Dansa Yesu Yesu Dansa Kaunatacce ya zo dubiya don

O kauna! Kauna ta sa Allah ya bada Dansa

Don haka, mu bada godiya ga Allah Uba ти ce

Ya Allah mun gode maka
God loved the world He gave His Son Jesus Jesus His beloved Son came to the world to ceton $m u$ save us

Oh Love! Made God give His son to save Don ceton $m u$ us.

Therefore, let us give thanks to God the father saying

O God, we thank you.

\section{O Ti Jinde - He Is Risen (Debo Akinwumi)}

O ti jinde, (3x) Oluwa wa a ti jinde

O ti jinde, (4x) Igbati Jesu wa saye

Nse lo n sise iyanu Nse lo n muni Larada

Nse lo n koni to $n$ Toni Nse lo n saa nu fun wa

Sugbon aye korii ro re. Aye ponon loju

Aye o fe otito kankan. Aye koo I' Oluwa

Asehinwa, asehinbo. A da a I'jooro

Ojiya tenu ko le so. O fara re rubo fun wa

O kuku oro lori igi. Nitorii re ate mi

O tijinde (3x) Oluwa wa jinde

Ife nla I'Olorunni saraye. To lomo re rubo

Fun Igbala wa. Ope loye o, Oluwa ami
He has risen(3x) Our Lord has risen

He has risen $(3 x)$ When Jesus came to the world He performed miracles and healed the sick

$\mathrm{He}$ was teaching and guiding He was merciful But the world hated him, the world despised him The world despised him. The world didn't love him

Eventually, he was judged

He was punished. He sacrificed himself

He died on the cross because of you and I

$\mathrm{He}$ has risen $(3 \mathrm{x})$. Our Lord is risen.

Great love God showed the world. He sacrificed his son.

For our salvation. Praise be to my Lord 
East African Journal of Traditions, Culture and Religion, Volume 2, Issue 1, 2020

Article DOI: https://doi.org/10.37284/eajtcr.2.1.226

Ope loye o. Eledumare O seun Eledumare O seun Praise be unto You. The creator, O thanks. Creator O Thanks

Ori ta de ladeegun. Ti de ade ogo

The head that wore the crown of thorns, wore the crown of glory

Ese olagbara mo. Kolagbara. Esu o lagbara mo

Sin has no more power. It has no power. Satan has no more power

Ko lagbara Iku o lagbara mo. Kolagbara

No more power, death has no more power. No more power

Niwon igbati oluwa waa ti jinde( $2 x)$

Immediately our Lord rose from the dead

Aye o lagbara mo. Ko lagbara Aje o lagbara mo

The creation has no more power. No more power, witches have no more power

Ko lagbara Emere o lagbara mo. Ko lagbara

No more power, evil spirits have no more power.

No more power

Jesu wa o ti jinde. Jinde kuro ninu iware

Jesus has risen. Rise up from your bad attitude

Jin de kuro ni nu ese re

Rise up from your sin

\section{Nitorii Re Ati Emi - Beacause of You and Me (Debo Akinwumi)}

Ibanuje ti po ju nile aye.

Aуе o roju то,

Aye di rudurudu.

Sebinitori wa l'Oba igbala se wa.

Ejeka di Jesu mu Kabale layo.

Nitori re lose wa saye

Nitori mi lofi wa saye

Lati saye dero,

lati fun wa ni ominira.

Lati fun wani isegun.

Lori ese ati esu.

lati rawapada kele deni iye.

Tobadi Jesu mu ekun o ni si mo.

Oro re awa dayo, o ro re a wa de rin

Oluwa, Oluwa, ayin o o, a wole fun o
The world is full of agony.

There is no way out of the world

The world is in confusion

It is because of us that our Saviour king came

Let us hold on to Jesus so we will have joy

He came to this world because of you

He came to this world because of me

To make the world a better place

To give us freedom

To give us victory

From sin and the devil

To deliver for us to have joy

If you hold on to Jesus, there will be no more cry

Your circumstance and situation will end in Joy

Lord, Lord we praise You, we bow before you 